\title{
Rancang Bangun Reverse Vending Machine Sampah Botol Plastik Dengan Alat Tulis
}

\author{
Pelangi Dwi Fathonah11, Hastuti ${ }^{2}$ \\ 1,2 Universitas Negeri Padang \\ Jl. Prof Dr. Hamka Air Tawar, Padang \\ pelangidwifa29@gmail.com,hastuti03@gmail.com
}

\begin{abstract}
The number of population is increasing from year to year so also with the use of plastic bottles has increased so that the plastic waste numbers are getting worse. Environmental pollution due to plastic waste is increasingly alarming, if no effort to resolve it. Therefore, this study designer of the heat exchanger where the waste of plastic bottles based on the Arduino Mega2560 and analyze the working system of infrared sensors that will be able to resolve the problem on plastic waste. Methods the design of this tool consists of hardware design and software design, some of the components used such as the microcontroller Arduino Mega2560, LCD, infrared sensor, and a servo motor. The design software on the system software use the Arduino IDE. Based on the results of design that has made the Arduino Mega2560 can work as a system control center tools and control some important parts of this equipment such as infrared sensor, infrared sensor can only detect objects a plastic bottle with a maximum distance of $1 \mathrm{~cm}$ then the infrared sensor will detect the bottle with the number of counter that have been specified on the program. The objective of this tool is expected to provide awareness to the community, especially the children not to throw trash haphazardly, because this tool will be applied in the school and can add knowledge for the students in the school that the waste dumped can though back.
\end{abstract}

Keywords - Reverse Vending Machine, Arduino Mega2560, Infrared Sensor, Plastic Bottle Garbage

\begin{abstract}
Abstrak - Jumlah penduduk semakin meningkat dari tahun ke tahun begitu juga dengan penggunaan botol plastik semakin meningkat sehingga sampah plastik jumlahnya semakin lama semakin bertambah. Pencemaran lingkungan akibat sampah plastik semakin mengkhawatirkan apabila tidak ada usaha untuk mengatasinya. Oleh karena itu dilakukan penelitian perancang alat penukar sampah botol plastik berbasis Arduino Mega2560 dan menganalisis sistem kerja dari sensor infrared yang nantinya dapat mengatasi permasalahan pada sampah plastik. Metode perancangan alat ini terdiri dari perancangan hardware dan perancangan software, beberapa komponen yang digunakan seperti mikrokontroler Arduino Mega2560, LCD, sensor infrared, dan motor servo. Perancangan software pada sistem ini menggunakan software IDE Arduino. Berdasarkan hasil perancangan yang telah dilakukan Arduino Mega2560 dapat bekerja sebagai sistem pusat kendali alat dan mengontrol beberapa bagian penting dari alat ini seperti sensor infrared, sensor infrared ini hanya dapat mendeteksi objek botol plastik dengan jarak maksimal $1 \mathrm{~cm}$ kemudian sensor infrared akan mendeteksi botol dengan jumlah counter yang telah ditentukan pada program. Tujuan dibuatnya alat ini diharapkan dapat memberikan kesadaran kepada masyarakat khususnya anak-anak untuk tidak membuang sampah sembarangan, karena alat ini akan diterapkan pada sekolah-sekolah dan dapat menambah pengetahuan bagi siswa di sekolah bahwa sampah yang dibuang dapat di olah kembali.
\end{abstract}

Kata kunci- Reverse Vending Machine, Arduino Mega2560, Sensor Infrared, Sampah Botol Plastik.

\section{Pendahuluan}

Sampah plastik semakin meningkat seiring bertambahnya jumlah produk dan pola konsumsi generasi milenial. Pencemaran lingkungan akibat sampah plastik semakin mengkhawatirkan apabila tidak ada usaha untuk mengatasinya. Masyarakat yang kurang pengetahuan dan berperilaku buruk dalam pengelolaan sampah plastik dapat menimbulkan gangguan kesehatan dan lingkungan[1][2][3]. Sampah terbagi menjadi tiga jenis, yaitu sampah organik, sampah anorganik, dan sampah berbahaya. Sampah organik yaitu sampah yang berasal dari alam dan mudah terurai seperti daun - daunan, kertas, kayu, dll. Lalu sampah anorganik adalah sampah yang berasal dari bahan non - hayati dan relatif lebih susah terurai dengan sendirinya. Sedangkan sampah berbahaya yaitu sampah yang beracun seperti bahan kimia, limbah pabrik, dll[4][5].

Untuk mengatasi permasalahan tentang pengolahan limbah plastik tersebut telah dilakukan beberapa penelitian tentang mesin penukaran sampah botol plastik, mesin ini akan menerima objek berupa limbah botol kemasan plastik yang digunakan sebagai input dan akan menanggapinya dengan mengeluarkan tiket berwarna. Dimana penelitian ini bertujuan untuk mengolah sampah plastik dan memberi kesadaran 
terhadap masyarat untuk membuang sampah pada tempatnya[6][7].

Tujuan pembuatan alat ini untuk memberikan kesadaran kepada masyarakat agar tidak membuang sampah sembarangan, dan dapat dijadikan media pembelajaran bagi anak-anak bahwa sampah tidak hanya untuk dibuang saja, tetapi sampah yang dibuang tadinya dapat di olah kembali.

Alat ini dapat digunakan pada sekolah-sekolah karena siswa di sekolah sangat membutuhkan alat tulis, dengan membuang sampah ke dalam alat ini mereka bisa mendapatkan alat tulis, sehingga siswa tidak perlu mengeluarkan uang untuk membeli alat tulis.

Pada penelitian yang dilakukan sebelumnya masih terdapat kekurangan pada sensor infrared yang digunakan,kemudian penukaran sampah yang sudah ada masih menggunakan tiket sebagai alat tukarnya, sehingga menjadi kurang efektif karena harus pergi ke loket untuk menukarnya menjadi uang. Untuk pembuatan mesin ini menggunakan beberapa sensor yang digunakan sebagai input, yaitu sensor infra red sebagai pendeteksi objek botol plastik yang masuk pada mesin. Mesin ini juga menggunakan motor servo yang berfungsi sebagai actuator yang dapat membuka tutup pada perlengkapan alat tulis yang dapat diambil secara langsung pada mesin.

Arduino Mega 2560 adalah papan mikrokontroller berbasiskan Atmega 2560. Arduino Mega 2560 memiliki 54 pin digital input/ouput. Dimana 15 pin dapat digunakan sebagai output PWM, 16 pin sebagai input analog, dan 4 pin sebagai UART (port serial hardware), $16 \mathrm{MHz}$ kristal osilator, koneksi USB, jack power, header ICSP, dan tombol reset.

Motor servo adalah sebuah motor DC dengan sistem umpan balik tertutup di mana posisi rotor-nya akan diinformasikan kembali ke rangkaian kontrol yang ada di dalam motor servo. Motor ini terdiri dari sebuah motor DC, serangkaian gear, potensiometer, dan rangkaian kontrol.

Sensor infrared merupakan sebuah modul sensor cerdas yang dapat digunakan untuk mendeteksi jarak objek. Keluaran proximity infrared berupa data digital yang menyatakan ada atau tidaknya obyek hingga jarak tertentu di depan sensor.

LCD (Liquid Cristal Display) adalah suatu jenis display elektronik yang dibuat dengan teknologi CMOS logic yang bekerja dengan tidak menghasilkan cahaya. LCD berfungsi sebagai penampil data baik dalam bentuk karakter, huruf, angka ataupun grafik. Komponen ini memiliki 16 pin, yang dapat digunakan untuk menampilkan 2x16 karakter.

Catu Daya atau sering disebut dengan Power Supply adalah sebuah piranti yang berguna sebagai sumber listrik untuk piranti lain. Pada dasarnya Catu Daya bukanlah sebuah alat yang menghasilkan energi listrik saja, namun ada beberapa Catu Daya yang menghasilkan energi mekanik, dan energi yang lain. Daya untuk menjalankan peralatan elektronik dapat diperoleh dari berbagai sumber.

\section{Metode}

Pada perancangan sistem ini secara keseluruhan terdiri dari dua perancangan yaitu perangkat lunak (software) dan perancangan perangkat keras (hardware). Perangkat keras terdiri dari beberapa komponen seperti mikrokontroler Arduino Mega2560, LCD, sensor infrared, motor servo dan botol plastik. Perancangan perangkat lunak pada sistem ini menggunakan software IDE Arduino. Alat penukaran sampah botol plastik ini menggunakan sistem kontrol otomatis diatur oleh Arduino Mega 2560 dengan menggunakan bahasa $\mathrm{C}++$ sebagai bahasa pemogramannya. Arduino mega 2560 terhubung dengan sensor infrared sebagai pendeteksi objek botol plastik yang masuk ke dalam alat.

Prinsip kerja dari alat ini yaitu pertama hidupkan tombol power pada alat penukaran sampah plastik. Selanjutnya masukan objek sampah botol plastik ke dalam alat sesuai dengan ukuran lobang yang sudah ada pada alat. Untuk ukuran lobang pada alat ini terdiri dari tiga bagian yaitu, kecil, menengah dan besar, dengan diameter $5 \mathrm{~cm}$ untuk ukuran botol plastik kecil, $7 \mathrm{~cm}$ untuk botol plastik ukuran menengah dan $10 \mathrm{~cm}$ untuk ukuran botol plastik besar. Setelah botol plastik dimasukan maka sensor infra red akan mendeteksi adanya objek berbahan plastik yang masuk ke dalam alat tersebut, kemudian alat ini akan mendeteksi berapa jumlah botol plastik yang dimasukan ke dalamnya. Alat ini hanya akan mengeluarkan alat tulis jika botol plastik yang dimasukkan sesuai dengan program yang telah dibuat, yaitu 4 sampah botol plastik untuk ukuran kecil, 3 sampah botol plastik untuk ukuran menengah dan 2 sampah botol plastik untuk ukuran besar. Setelah sensor infra red mendeteksi adanya sampah botol plastik yang masuk, maka alat ini akan mengaktifkan motor servo untuk membuka katup pada kotak alat tulis yang ada di dalam alat tersebut.

\section{A. Blok Diagram}

Dibawah ini merupakan blok diagram dari perancangan dan pembuatan alat Reverse Vending Machine Penukaran Sampah Botol Plastik dengan Alat Tulis: 


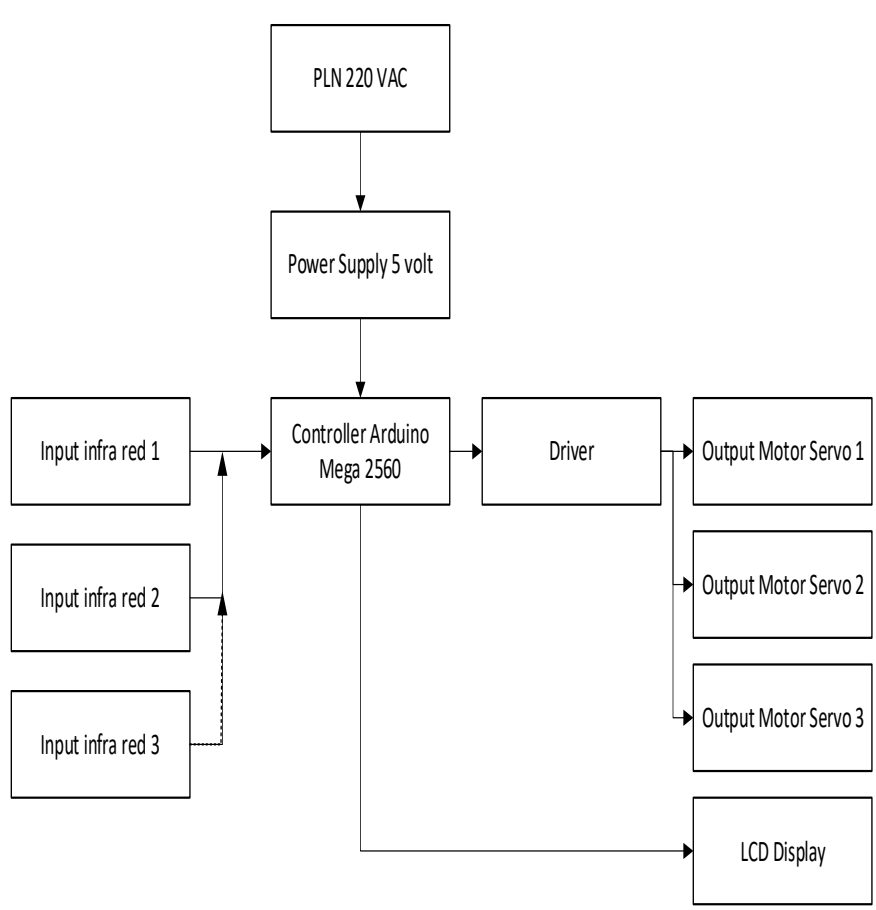

Gambar 1. Blok Diagram Sistem Kerja Alat

Dari blok diagram diatas dijelaskan sebagai berikut:

Power Supply berfungsi untuk sumber listrik pada Mikrokontroller Arduino Mega 2560. Arduino Mega 2560 merupakan bagian yang berfungsi sebagai sistem kontrol untuk memproses input yang dimasukan dan menghasilkan output berupa aktifasi pada motor servo untuk mengeluarkan alat tulis. Ketika sensor infrared menerima data dari hasil pembacaan botol yang dimasukkan ke dalam alat, maka sensor infrared akan mengirimkan data hasil pembacaan ini ke Arduino Mega 2560 untuk diproses guna menentukan alat tulis mana yang akan keluar. Selanjutnya Arduino Mega 2560 akan memerintahkan motor servo untuk membuka pintu penahan pada alat tulis yang akan di keluarkan, motor servo akan mengeluarkan alat tulis sesuai jumlah botol yang dimasukan. Kemudian Arduino Mega2560 akan memerintahkan LCD untuk menampilkan hasil pembacaan dari sensor infrared.

\section{B. Perancangan Hardware}

\section{Perancangan Mekanik}

Perancangan mekanik alat ini menggunakan bahan akrilik dengan ketebalan $2 \mathrm{~mm}$. Alat ini dilengkapi dengan tiga buah lubang dengan diameter masing-masing $10 \mathrm{~cm}, 7 \mathrm{~cm}$, dan $5 \mathrm{~cm}$, lobang yang dibuat ini disesuaikan dengan ukuran botol plastik yang dimasukan pada alat tersebut.

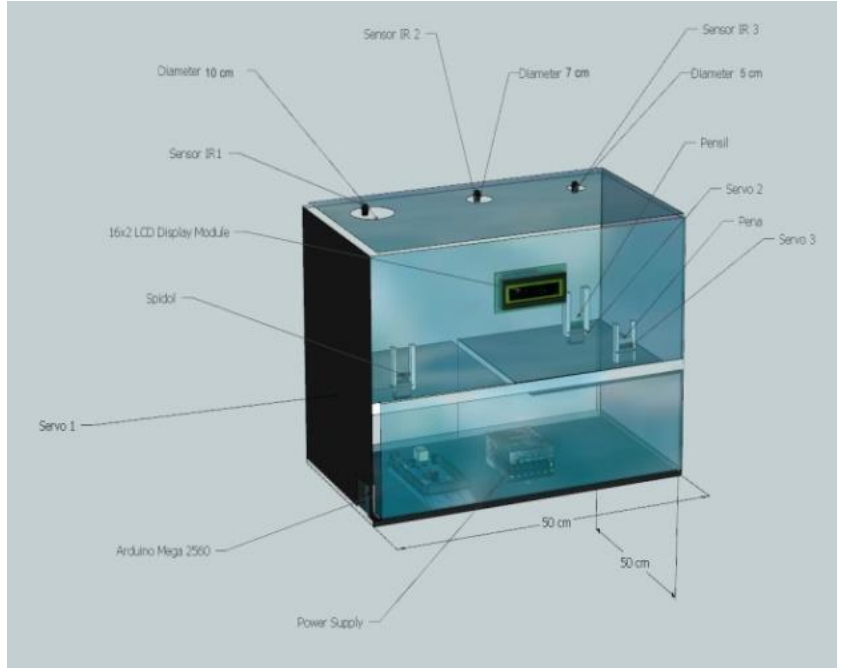

Gambar 2. Desain Mekanik Tampak Depan

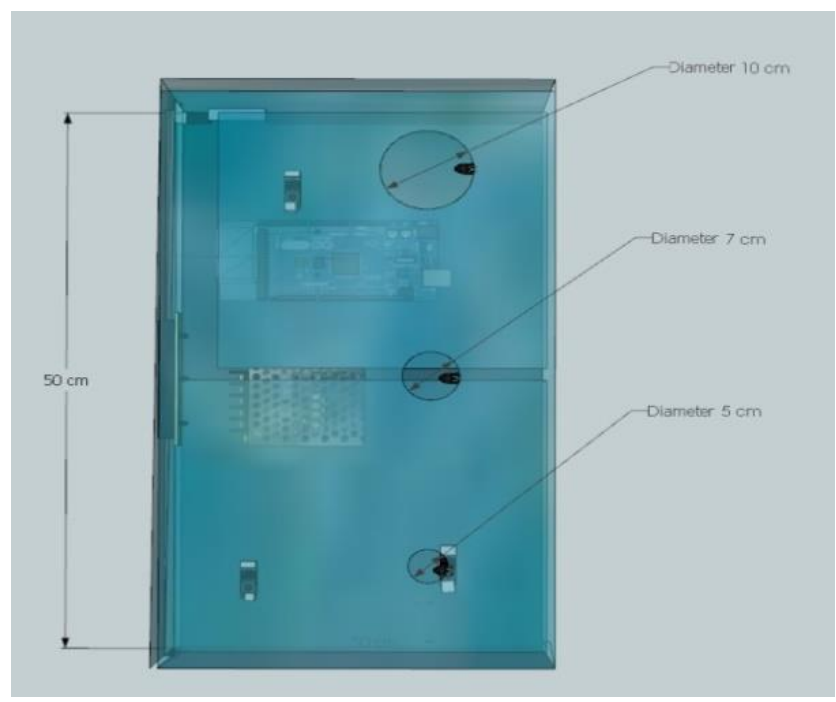

Gambar 3. Desain Mekanik Tampak Atas

2. Perancangan Rangkaian Elektronika Keseluruhan

Untuk rangkaian keseluruhan yang terdiri dari Infra Red, Arduino Mega, Motor Servo, dan LCD dapat dilihat semua komponen elektronika tersebut pada gambar dibawah ini :

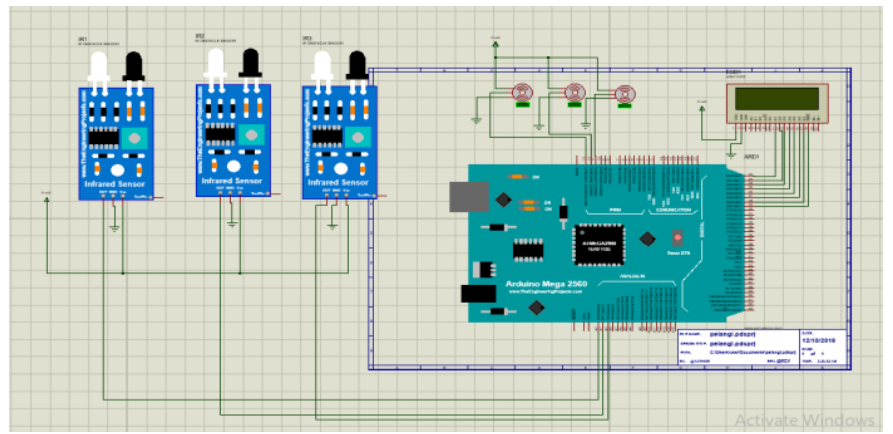

Gambar 4 : Rangkaian Elektronika Keseluruhan 


\section{Perancangan Software}

Perancangan software pada tugas akhir ini dimulai dengan mendesain flowchart secara detail serta membuat program menggunakan Arduino IDE. Pada pemodelan flowchart ini terdapat instruksi - instruksi dari program yang akan dibuat.

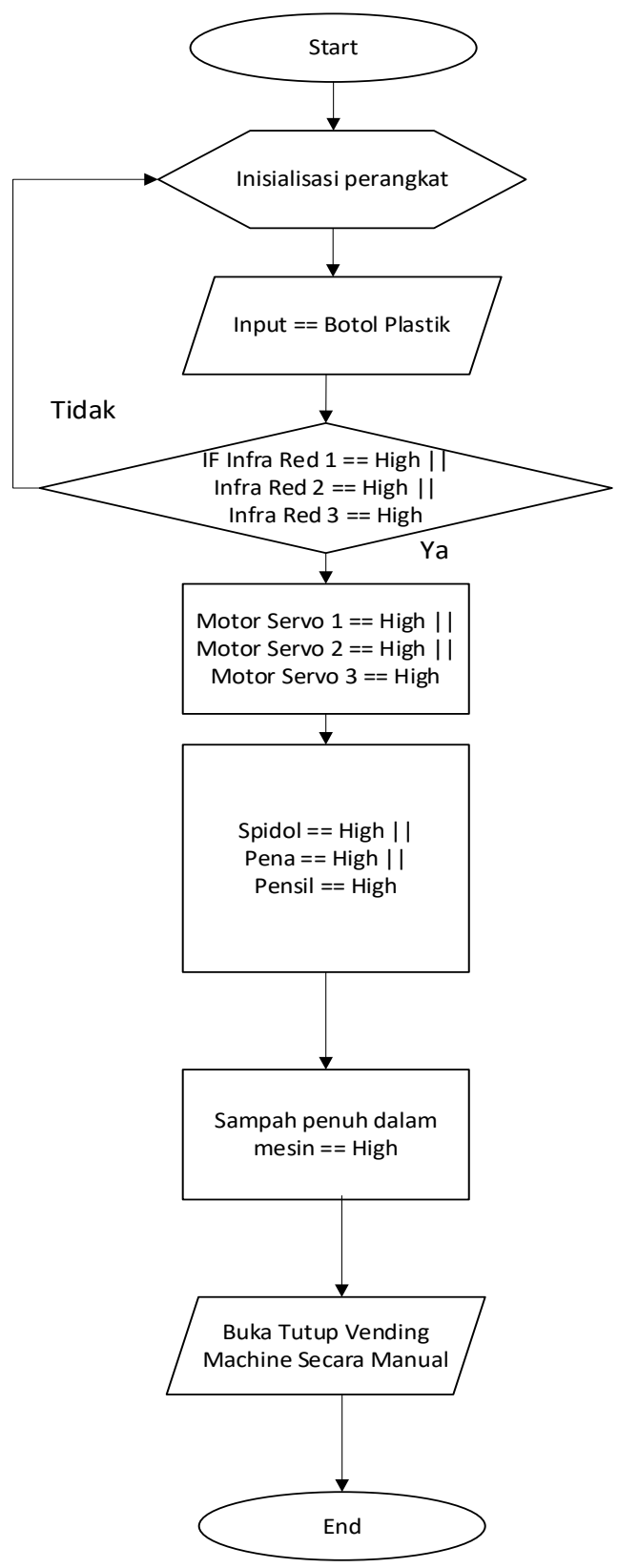

Gambar 5. Flowchart Sistem Keseluruhan

Pada saat perangkat mulai dinyalakan, maka perangkat akan melakukan proses menginialisasi terlebih dahulu. Setelah proses inisialisasi perangkat selesai, selanjutnya masukan objek botol plastik ke dalam mesin. Setelah botol plastik dimasukan maka botol plastik tersebut akan terdeteksi oleh sensor infra red. Apabila sensor infra red 1 mendeteksi botol plastik, maka motor servo 1 akan membuka katup pada spidol. Lalu apabila sensor infrared 2 mendeteksi botol plastik, maka motor servo 2 akan aktif dan membuka katup pada pena. Dan seterusnya apabila pada sensor infra red 3 mendeteksi botol plastik, maka motor servo 3 akan aktif dan membuka katup pensil.

\section{HASIL DAN PEMBaHASAN}

Pada bagian ini dilakukan beberapa pengujian dan analisa pada seluruh bagian input dan output. Pengujian dan analisa sensor yang dilakukan untuk mengetahui apakah sensor yang digunakan berfungsi dengan baik atau tidak sebagai input sesuai dengan perancangan awal. Pengujian alat ini dimulai dengan menekan tombol power pada alat,kemudian memasukkan input botol plastik dan melihat apakah sensor bekerja dengan baik. Alat ini memiliki ukuran Gambar 6 berikut ini merupakan bentuk alat keseluruhan.

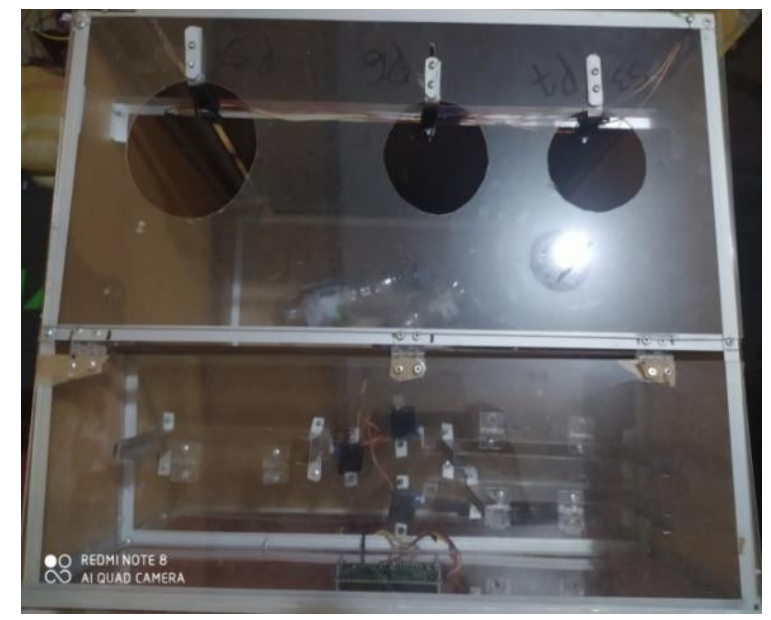

Gambar 6. Bentuk Alat Tampak Atas

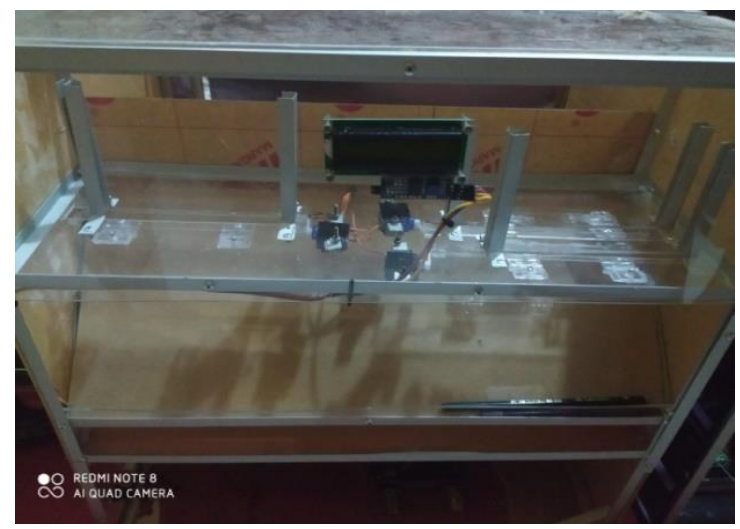

Gambar 7 . Bentuk Alat Tampak Depan 
Untuk ukuran alat ini memiliki tinggi $50 \mathrm{~cm}$, panjang $50 \mathrm{~cm}$ dan lebar $40 \mathrm{~cm}$. Bentuk fisik alat jika dilihat dari atas pada gambar 18, terdapan 3 buah lobang dengan ukuran yang berbeda, fungsinya untuk memasukkan sampah botol plastik kedalam mesin.

\section{Pengujian Kinerja Sistem}

Pengujian keseluruhan sistem dilakukan untuk mengetahui apakah sistem sudah bekerja dengan baik.Fungsi dari semua bagian alat akan diperhatikan kinerjanya, baik itu input maupun output. Setelah pengujian selesai, alat akan dinonaktifkan kembali. Tabel di bawah menunjukkan hasil pengujian sensor infrared:

Tabel 1. Pengujian Sensor Infrared

\begin{tabular}{|c|c|c|c|c|c|}
\hline Objek & $\begin{array}{l}\text { Jarak } \\
\text { (cm) }\end{array}$ & $\begin{array}{l}\text { Kondisi } \\
\text { Sensor } \\
\end{array}$ & $\begin{array}{l}\text { Hasil } \\
\text { Pengujian }\end{array}$ & $\begin{array}{l}\text { Persentase } \\
\text { (\%) }\end{array}$ & $\begin{array}{l}\text { Error } \\
(\%)\end{array}$ \\
\hline $\begin{array}{l}\text { Botol } \\
\text { Plastik }\end{array}$ & 1 & HIGH & Terdeteksi & \multirow{9}{*}{$\frac{12}{15} \times 100 \%$} & \multirow{9}{*}{$20 \%$} \\
\hline $\begin{array}{l}\text { Botol } \\
\text { Plastik }\end{array}$ & 1 & $\mathrm{HIGH}$ & Terdeteksi & & \\
\hline $\begin{array}{l}\text { Botol } \\
\text { Plastik }\end{array}$ & 1 & HIGH & Terdeteksi & & \\
\hline $\begin{array}{l}\text { Botol } \\
\text { Plastik }\end{array}$ & 0,5 & HIGH & Terdeteksi & & \\
\hline $\begin{array}{l}\text { Botol } \\
\text { Plastik }\end{array}$ & 0,5 & HIGH & Terdeteksi & & \\
\hline $\begin{array}{l}\text { Botol } \\
\text { Plastik }\end{array}$ & 0,5 & $\mathrm{HIGH}$ & Terdeteksi & & \\
\hline $\begin{array}{l}\text { Botol } \\
\text { Plastik }\end{array}$ & 0,3 & HIGH & Terdeteksi & & \\
\hline $\begin{array}{l}\text { Botol } \\
\text { Plastik }\end{array}$ & 0,3 & $\mathrm{HIGH}$ & Terdeteksi & & \\
\hline $\begin{array}{c}\text { Botol } \\
\text { Plastik }\end{array}$ & 0,3 & HIGH & Terdeteksi & & \\
\hline
\end{tabular}

Dari tabel diatas dapat dikatakan bahwa rangkaian pada sensor infrared telah bekerja dengan baik. Pengujian sensor infrared yang dilakukan pada botol plastik, pada saat botol memantulkan cahaya infrared yang dipancarkannya maka sensor akan mendeteksi botol dengan jarak maksimal $1 \mathrm{~cm}$, dengan pengujian sebanyak 15 kali maka didapatkan kegagalan sebanyak 3 kali, hal ini disebabkan karena jarak antara sensor infrared dengan botol terlalu jauh, sehingga sensor tidak dapat mendeteksi botol.
Tabel 2. Hasil Pengujian Keseluruhan

\begin{tabular}{|c|c|c|c|c|}
\hline $\begin{array}{c}\text { Jumlah } \\
\text { Botol }\end{array}$ & Input & Ouput & Jarak & $\begin{array}{c}\text { Hasil } \\
\text { Pengujian }\end{array}$ \\
\hline $\begin{array}{l}2 \text { Botol } \\
\text { Plastik } \\
\text { Besar }\end{array}$ & $\begin{array}{l}\text { Sensor } \\
1\end{array}$ & $\begin{array}{l}\text { Motor } \\
\text { Servo } 1\end{array}$ & $1 \mathrm{~cm}$ & Terdeteksi \\
\hline $\begin{array}{l}2 \text { Botol } \\
\text { Plastik } \\
\text { Besar }\end{array}$ & $\begin{array}{l}\text { Sensor } \\
1\end{array}$ & $\begin{array}{l}\text { Motor } \\
\text { Servo } 1\end{array}$ & $2 \mathrm{~cm}$ & $\begin{array}{l}\text { Tidak } \\
\text { Terdeteksi }\end{array}$ \\
\hline $\begin{array}{l}1 \text { Botol } \\
\text { Plastik } \\
\text { Besar }\end{array}$ & $\begin{array}{l}\text { Sensor } \\
1\end{array}$ & $\begin{array}{l}\text { Motor } \\
\text { Servo } 1\end{array}$ & $1 \mathrm{~cm}$ & $\begin{array}{l}\text { Tidak } \\
\text { Terdeteksi }\end{array}$ \\
\hline
\end{tabular}

3 Botol $\begin{array}{lllll}\text { Plastik } & \text { Sensor } & \text { Motor } & 1 \mathrm{~cm} & \text { Terdeteksi } \\ \text { Meneng } & 2 & \text { Servo 2 } & & \end{array}$ ah

$\begin{array}{lllll}\begin{array}{l}3 \text { Botol } \\ \text { Plastik }\end{array} & \text { Sensor } & \text { Motor } & 2 \mathrm{~cm} & \text { Tidak } \\ \text { Meneng } & 2 & \text { Servo 2 } & & \text { Terdeteksi }\end{array}$

ah

\begin{tabular}{lllll}
$\begin{array}{l}2 \text { Botol } \\
\text { Plastik }\end{array}$ & Sensor & Motor & $1 \mathrm{~cm}$ & Tidak \\
$\begin{array}{l}\text { Meneng } \\
\text { ah }\end{array}$ & 2 & Servo 2 & & Terdeteksi \\
\hline
\end{tabular}

\begin{tabular}{lllll}
$\begin{array}{l}\text { 4 Botol } \\
\text { Plastik } \\
\text { Kecil }\end{array}$ & $\begin{array}{l}\text { Sensor } \\
3\end{array}$ & $\begin{array}{l}\text { Motor } \\
\text { Servo } 3\end{array}$ & $1 \mathrm{~cm}$ & Terdeteksi \\
\hline $\begin{array}{l}\text { 4 Botol } \\
\text { Plastik }\end{array}$ & $\begin{array}{l}\text { Sensor } \\
\text { Kecil }\end{array}$ & $\begin{array}{l}\text { Motor } \\
\text { Servo } 3\end{array}$ & $2 \mathrm{~cm}$ & $\begin{array}{l}\text { Tidak } \\
\text { Terdeteksi }\end{array}$ \\
\hline $\begin{array}{l}\text { B Botol } \\
\text { Plastik }\end{array}$ & Sensor & Motor & $1 \mathrm{~cm}$ & $\begin{array}{l}\text { Tidak } \\
\text { Kecil }\end{array}$ \\
\hline
\end{tabular}

Dari hasil pengujian tabel diatas, dapat diketahui bahwa jika sensor 1 dilewati oleh botol plastik sebanyak 2 kali dengan jarak $1 \mathrm{~cm}$, maka motor servo 1 akan aktif dan membuka pintu spidol, kemudian jika sensor 1 dilewati oleh botol plastik sebanyak 2 kali dengan jarak $2 \mathrm{~cm}$, maka motor servo tidak aktif, dan jika sensor 1 dilewati botol plastik sebanyak 1 kali dengan jarak $2 \mathrm{~cm}$, maka motor servo juga tidak aktif. Seterusnya jika sensor 2 dilewati botol plastik sebanyak 3 kali dengan jarak $1 \mathrm{~cm}$, maka motor servo 2 akan aktif dan membuka pintu pensil. kemudian jika sensor 2 dilewati oleh botol plastik sebanyak 3 kali dengan jarak $2 \mathrm{~cm}$, maka motor servo tidak aktif, dan jika sensor 2 dilewati botol plastik sebanyak 2 kali dengan jarak $1 \mathrm{~cm}$, maka motor servo 2 
tidak aktif. Dan seterusnya jika sensor 3 dilewati oleh botol plastik sebanyak 4 kali dengan jarak $1 \mathrm{~cm}$, maka motor servo 3 akan aktif dan membuka pintu pulpen, kemudian jika sensor 3 dilewati botol plastik sebanyak 4 kali dengan jarak $2 \mathrm{~cm}$, maka motor servo 3 tidak aktif, dan jika sensor 3 dilewati botol plastik sebanyak 3 kali dengan jarak $2 \mathrm{~cm}$, maka motor servo tidak aktif.

\section{Penutup}

Berdasarkan pengujian yang telah dilakukan, alat penukaran sampah botol plastik ini telah berjalan sesuai dengan tujuan yang dibuat, dimana Arduino Mega2560 bekerja sebagai sistem pusat kendali dari alat. Arduino Mega2560 mengontrol beberapa bagian penting dari alat ini, yaitu sensor infrared, motor servo, dan LCD. Pada pengimplementasian ini tentunya dimasukkan program pendukung untuk mengatur bagian pada kontrolnya. Hasil pengujian yang telah dilakukan pada Sensor Infrared, sensor ini hanya dapat mendeteksi objek botol plastik dengan jarak maksimal $1 \mathrm{~cm}$ kemudian sensor infrared akan mendeteksi botol dengan jumlah counter yang telah ditentukan pada program.

Dalam proses pembuatan alat ini tentunya ada kelemahan serta kekurangan yang dihasilkan. Untuk pendeteksian sensor alangkah lebih baiknya diganti dengan yang lebih presisi, karena jarak yang dideteksi oleh sensor tcrt5000 tersebut hanya akan mendeteksi jarak dibawah $1 \mathrm{~cm}$.

\section{REFERENSI}

[1] I. G. A. A. Y. Dewi, "The Role of Millennial Generation in Plastic Waste Management in Penatih Dangin Puri Village, East Denpasar District, Denpasar City," Public Inspir. J. Adm. Publik, vol. 3, no. 2, pp. 84-92, 2018.

[2] R. Setyowati and S. A. Mulasari, "Pengetahuan dan Perilaku Ibu Rumah Tangga dalam Pengelolaan Sampah Plastik," Kesmas Natl. Public Heal. J., vol. 7, no. 12, p. 562, 2013, doi: 10.21109/kesmas.v7i12.331.

[3] F. Burlian, I. Yani, J. Arie S, and Ivfransyah,
"Rancang Bangun Alat Penghancur Sampah Botol Plastik Kapasitas $\pm 33 \mathrm{Kg} / \mathrm{Jam}$ Firmansyah," Semin. Nas. Teknoka, vol. 4, no. 2502, pp. 15-19, 2017, doi: 10.22236/teknoka.v.

[4] M. T. M Hariansyah, A. Eldine, and others, "Pengembangan Teknologi Tepat Guna Dalam Pengelolaan Sampah Plastik," Neraca Keuang., vol. 11, no. 2, pp. 31-40, 2016.

[5] R. Rarasati and T. Pradekso, "Pengaruh Terpaan Berita Satwa Laut Yang Mati Akibat Sampah Plastik dan Kampanye Zero Waste Terhadap Perilaku Pengurangan Penggunaan Kantong Plastik," Interak. Online, vol. 7, no. 4, pp. 295-304, 2019.

[6] P. Handoko, H. Hermawan, and S. Jaya, "Reverse Vending Machine Penukaran Limbah Botol Kemasan Plastik Dengan Tiket Sebagai Alat Tukar Mata Uang," Semin. Nas. Sains dan Teknol. 2018, pp. 1-12, 2018.

[7] B. Ibrahim and A. Rifa, "Perancangan Reverse Vending Machine Khusus Botol Kaleng Dan Plastik Yang Dapat Diterapkan Di Indonesia," Nasional, vol. 2, no. 1, 2015.

\section{Biodata Penulis}

Pelangi Dwi Fathonah, lahir di Koto Baru, 16 Oktober 1997. Menyelesaikan Program Studi DIV Teknik Elektro Industri pada Jurusan Teknik Elektro di Fakultas Teknik Universitas Negeri Padang.

Hastuti, S.T,M.T, lahir di Tembilahan, 25 Mei 1976. Menyelesikan Studi S1 Sarjana Teknik Elektro di Jurusan Teknik Elektro Universitas Andalas. Memperoleh gelas Master Teknik di Sekolah Teknik Elektro dan Informatika (STEI) ITB Bidang Sistem Kendali. Staf pengajar di Jurusan Teknik Elektro FT-UNP Sejak tahun 2008 s.d sekarang. 